\title{
"NISI CREDIDERITIS, NON INTELLIGETIS": A INTELIGÊNCIA DA FÉ EM SANTO AGOSTINHO
}

\author{
"NISI CREDIDERITIS, NON INTELLIGETIS": \\ INTELLIGENCE OF FAITH IN SAINT AUGUSTINE
}

Daniel Chacon*

\section{RESUMO}

O objetivo deste artigo consiste em elucidar o problema da inteligência da fé cristã a partir de Santo Agostinho. Nesse sentido, o bispo de Hipona realizou uma síntese pela dialética que pode ser compreendida a partir da máxima credo ut intelligam, intelligo ut credam. O método proposto neste labor acadêmico será o da revisão bibliográfica. As considerações desenvolvidas nesta pesquisa situam-se na perspectiva de que a conciliação proposta por Santo Agostinho consiste em pensar a relação entre fé e razão, sem, contudo, pressupor uma rejeição arbitrária da fé ou uma atitude irracionalista frente a este drama. No horizonte dessa síntese, no entanto, o problema da racionalidade da fé não se resolve sumariamente; antes, para além de uma simples discussão restrita à antiguidade tardia, o esforço de elucidação da inteligência da fé é ainda um complexo dilema para a inteligência contemporânea.

PALAVRAS-chaVE: Santo Agostinho. Fé. Razão. Intellectus fidei.

\section{ABSTRACT}

This article aims to elucidate the problem of intelligence of faith based on Saint Augustine. In this sense, the bishop of Hippo held conciliation from a dialetic that can be understood by the maxim credo ut intelligam, intelligo ut credam. The

* Mestre em Filosofia pela Faculdade Jesuíta de Filosofia e Teologia; Especialista em Ciências da Religião e em Educação (Inspeção Escolar e Supervisão Escolar) e Licenciado em Pedagogia, ambos pela Faculdade de Educação e Tecnologia - Fetremis; Licenciado em Filosofia pela Universidade Católica de Brasília, Bacharelando em Filosofia na Faculdade Jesuíta de Filosofia e Teologia e Bacharel em Teologia pelo Centro Universitário Metodista Izabela Hendrix (FATE-BH).

\begin{tabular}{|l|l|l|l|l|l|}
\hline Teocomunicação & Porto Alegre & v. 45 & n. 3 & p. 247-268 & set.-dez. 2015 \\
\hline
\end{tabular}


method in use in this academic work is the literature review. The considerations developed in this research are from the perspective that the conciliation held by Saint Augustine concerned the possibility of thinking the relationship between faith and reason without assuming an arbitrary rejection of faith, or an irrational attitude towards this drama. On the horizon of this synthesis, however, the problem of rationality of faith was not definitively sorted out, but beyond a simple discussion concerned to late antiquity, the effort to elucidate the intelligence of faith is furthermore a complex dilemma for the contemporary intelligence.

Keywords: Saint Augustin. Faith. Reason. Intellectus fidei.

\section{Introdução}

Em face das exigências epistêmicas do gênio grego, o cristianismo refletiu sobre a racionalidade de sua própria fé e, a partir dela, desenvolveu uma interpretação singular dos dilemas essenciais que interpelaram a cultura helenística da antiguidade tardia. Nesse cenário, Santo Agostinho, o grande Doutor ocidental, como é conhecido na tradição cristã, destacou-se por ser o responsável por erigir a primeira grande síntese teológico-filosófica. À luz das correntes do pensamento patrístico grego e latino, ele realizou uma ampla conciliação do dilema fé e razão. A síntese por ele proposta tornou-se a forma mais elevada de especulação filosófica e teológica que a antiguidade tardia desenvolveu, e seu "filosofar na fé" veio a ser, certamente, um predicado indelével da inteligência cristã ${ }^{1}$.

Nesse horizonte, o aforismo nisi credideritis, non intelligetis, ou seja, "se não crerdes, não compreendereis", manifestou-se, pois, no centro da síntese agostiniana. Conforme postulou Santo Agostinho, a fé é indispensável para o alcance da Verdade, pois ela descreve uma espécie de esperança, um horizonte de intelecção que deve ser almejado pela razão. Ora, a fé, particularmente nas Escrituras, proporciona os axiomas a partir dos quais se deve investigar, a fim de se alcançar a Verdade Eterna. Com efeito, a fé é uma exigência indeclinável para alcançar a inteligência.

1 Cf. JOÃO PAULO II, Fides et ratio. Ainda, conforme Gareth B. Matthews: "Com apenas um leve exagero, poderíamos dizer que santo Agostinho inaugurou a consideração filosófica de muitos tópicos que são hoje aceitos como questões correntes na filosofia da religião. Um desses tópicos é ‘Fé e Razão'” (cf. MATTHEWS, Fé e razão, p. 135). 
Destarte, pretende-se destacar aqui, ainda que sumariamente, a singularidade da inteligência da fé pensada a partir da dialética credo ut intelligam, intelligo ut credam ${ }^{2}$ em Santo Agostinho.

\section{Crer para compreender, compreender para crer}

A questão do sentido e significado de crer em Santo Agostinho requer, inicialmente, uma leitura que aproxime os principais textos de seu corpus que versam sobre esse dilema ${ }^{3}$. Nesse horizonte, a obra De praedestinatione sanctorum ${ }^{4}$, de cerca de 428-429 d.C. 5 , constitui referência indispensável. Aí, Agostinho forneceu uma célebre definição formal do significado de crer: "Assim acontece, embora o ato de crer nada mais seja que pensar com assentimento"6. É bem verdade que a presente definição aparece num contexto singular. O que estava em jogo,

2 Ainda que essa fórmula não tenha sido, de modo ipsis litteris, cunhada pelo próprio Agostinho, certamente ela expressa a natureza dialógica da conciliação agostiniana, conforme apontaremos aqui.

3 Contudo, Oliver Du Roy, em L'intelligence de la foi en la Trinité selon Saint Augustin, sugere, corretamente, que qualquer estudo sobre o pensamento de Santo Agostinho deve respeitar a cronologia de seus escritos (p. 15). Nesse sentido, a própria definição e relação dos termos fé e razão devem ser interpretados à luz das exigências impostas por seus interlocutores imediatos, pois a ênfase atribuída a cada um desses termos surge como resposta a essas exigências que, por força, são simetricamente opostas (cf. NOVAES FILHO, A razão em exercício, p. 93-94). Reconhecer, então, essa questão, não equivale a afirmar a existência de uma impossibilidade radical de se perceber a relação fé e razão a partir de um todo. Antes, o que se comunica aqui é que cada texto do corpus agostiniano deve ser, necessariamente, compreendido a partir de seu contexto imediato. A necessidade de contextualização não significa, também, que o exercício de diálogo pela aproximação das obras de Santo Agostinho, mesmo entre aquelas produzidas em cenários bem distintos, seja, em si mesmo, um absurdo. Com efeito, a relação pode ser legítima e demasiadamente rica se, e somente se, considerar o horizonte de particularidade de cada texto, pois conforme alerta Marrou seria um equívoco se interpretar um termo agostiniano simplesmente tomando um texto de uma obra diferente (cf. MARROU, Saint Augustin et la fin de la culture antique, p. 246). Muito embora Étienne Gilson também tenha considerado o problema da existência de certa flutuação nos conceitos agostinianos, ele mesmo fixou alguns pontos comuns na interpretação de importantes terminologias desta filosofia (cf. GILSON, 2010, p. 96). Pressupor, portanto, uma ambiguidade absoluta na compreensão dos conceitos agostinianos seria um enorme equívoco. Destarte, pretende-se fazer uma aproximação entres essas obras, respeitando, entretanto, suas menores nuanças, a fim de evitar sérios problemas. Não ambicionamos, entretanto, esgotar o conteúdo desses textos.

4 As citações deste texto remetem à tradução do Frei Agustino Belmonte. Contudo, as referências às obras agostinianas manterão a padronização clássica das versões latinas.

5 LANCEL, S. Saint Augustin.

6 De praedestinatione sanctorum, II, 5. 
ali, era a polêmica com os pelagianos. Segundo estes, a crença não era, rigorosamente, uma dádiva de Deus, senão somente aumentada por ele, em razão do mérito segundo o qual a própria fé se iniciou naquele que crề

Em oposição aos pelagianos, Agostinho sustentou que a crença, por si mesma, já era uma dádiva da graça divina. Retomou, pois, um excerto bíblico que diz: "Não que sejamos capazes de pensar alguma coisa, como se viesse de nós mesmos; mas a nossa capacidade vem de Deus" (2Cor. 3,5). Se, como expresso neste texto, não é possível prescindir de Deus na cogitatio, isto é, se o ser humano não é capaz de cogitar de maneira autossuficiente, soberana, então não é dado ao ser humano produzir por si mesmo a crença, pois, a crença é um cogitar com assentimento. Considerar, portanto, a fé como condição ex nobis, ou seja, uma virtude simplesmente produzida pelo gênero humano seria, na perspectiva agostiniana, um grave equívoco ${ }^{8}$.

$\mathrm{Na}$ esteira desse argumento, encontra-se, portanto, sua clássica concepção de crença:

Quem não vê que primeiro é pensar e depois crer? Ninguém acredita em algo, se antes não pensa no que há de crer. Embora certos pensamentos precedam de um modo tão instantâneo e rápido a vontade de crer, e esta vem em seguida e é quase simultânea ao pensamento, é mister que os objetos da fé recebam acolhida depois de terem sido pensados. Assim acontece, embora o ato de crer nada mais seja que pensar com assentimento. Pois, nem todo o que pensa, crê, havendo muitos que pensam, mas não creem, mas todo aquele que crê pensa, e pensando crê e crê pensando?.

Segundo esta definição, o pensar se antepõe ao crer, pois é necessária a existência de uma estrutura cognoscível a priori no ser humano como condição fundamental para se crer. As crenças só podem ser admitidas se, e somente se, forem, em certa medida, compreendidas ${ }^{10}$. Enfatiza-se aqui a expressão "em certa medida", porque, para se crer, não se necessita ter alcançado a plena compreensão racional dos conteúdos da fé. Antes, a plena compreensão só se alcança por meio da própria fé. A

\footnotetext{
7 Cf. Ibidem, II, 3.

8 KOCH, I. Sobre a definição agostiniana de crença, p. 15-24.

9 De praedestinatione sanctorum, II, 5.

${ }^{10}$ STEAD, C. A filosofia na antiguidade cristã.
} 
condição, então, a que se refere aqui seria uma espécie de preparação para a fé por meio da razão ${ }^{11}$.

Semelhante concepção se encontra no Sermo XLIII. Nesta homilia, Agostinho realizou um intrigante comentário à Segunda Epístola de Pedro 1,18. Sua reflexão inicia com uma importante definição de fé: "A fé consiste em crer no que não se vê, e sua recompensa é ver o que se crê" 12 . Os termos dessa definição remontam ao que foi dito aqui anteriormente, isto é: que a fé consiste numa etapa necessária para a obtenção do conhecimento de Deus, seguida posteriormente da contemplação do conteúdo apontado pela fé. Nesse sentido, a fé é compreendida como propedêutica à beatitude.

Mais adiante, nosso filósofo-teólogo expressa sua compreensão da origem da fé: "Nem sequer da fé podemos nos gloriar como se de nós dependesse. [...] Pois, o que tens que não tenhas recebido?"13. Nesse sentido, a fé não se originaria no ser humano como um mérito de seu próprio esforço, divergindo, assim, da alegação pelagiana, conforme se descreveu no De praedestinatione sanctorum. De modo contrário ao que ensinava Pelágio, a fé teria sua origem em Cristo, conforme também afirmou o autor do texto bíblico de Hebreus: "com os olhos fixos naquele que é o iniciador e consumador da fé, Jesus [...]” (Heb 12,2).

Entretanto, essa questão não corresponde ao problema central da homilia. A despeito dessa afirmação, Agostinho, diferentemente do que acontece no De praedestinatione sanctorum, não direciona seu sermão a uma disputa com os pelagianos. O aspecto capital de seu sermão se encontra na descrição dada da relação entre fé e razão. Interpelado sobre tal questão, Santo Agostinho argumentou:

Alguém me diz: 'Tenho que entender para crer'. Respondo-lhe: 'Creia para entender'. Havendo, pois, surgido entre nós uma espécie de controvérsia a esse respeito, de modo que ele me diz: 'Tenho que entender para crer' e eu lhe respondo: 'Pois bem, creia para entender' ${ }^{14}$.

\footnotetext{
${ }^{11}$ É nesse sentido que Gilson (Introdução ao estudo de Santo Agostinho, p. 64) alega que se instaura o primeiro instante da relação fé e razão.

12 Sermo XLIII, 1. Tradução nossa, aqui e alhures, a partir da versão espanhola da Biblioteca de Autores Cristianos.

13 Sermo XLIII, 1.

14 Sermo XLIII, 3.
} 
A clareza com que o complexo dilema entre fé e razão é discutido nessa homilia torna a reflexão sobre a temática extremamente convidativa. A experiência pastoral do bispo de Hipona e, por conseguinte, sua preocupação em instruir mesmo os fiéis mais néscios quanto à inteligência cristã, fazem deste sermão uma referência singular e indispensável ao tratamento da questão na antiguidade tardia.

Examinando esse dilema, Santo Agostinho remontou seu argumento à autoridade judicativa do profeta Isaías, que, conforme a tradução latina conhecida por Agostinho, teria dito: "Nisi credideritis non intelelligetis" 15 , ou seja, "se não crerdes, não compreendereis". Não deixando dúvidas quanto a isso, o bispo de Hipona reafirmou: "Ut intelligas crede" 16 - "creia para compreender"17. Contudo, o reconhecimento da necessidade de uma estrutura a priori no ser humano como condição de possibilidade para a fé se expressa com nitidez nesse sermão. Diante da alegação de quem o interpelou, ele reconheceu:

Portanto, amados, aquele a quem me opus, dando origem a uma controvérsia que me levou a pedir um profeta como juiz, não profere palavras vazias de significado quando disse: 'Tenho que compreender para crer'. Pois, certamente, o que agora mesmo estou falando, falo para que creiam os que ainda não creem. E, porém, se não entendem o que falo, não podem crer. Portanto, de certo modo é verdadeiro o que ele disse: 'Tenho que compreender para crer'; assim como é verdadeiro o que eu disse a partir do profeta: 'Pois, creia para compreender'. Ambos dizemos a verdade: coloquemo-nos de acordo. Consequentemente, compreenda para crer, creia para compreender. Em poucas palavras vou dizer como devemos entender um e outro sem problema algum. Compreenda minha palavra para crer, creia na palavra de Deus para compreendê-la ${ }^{18}$.

Eis, portanto, o desfecho do Sermo XLIII. Em confronto com o dilema exposto, Agostinho remata: "Intellege, ut credas, verbum meum; crede, ut intellegas, verbum Dei"19. Afirmar, entretanto, a anterioridade

\footnotetext{
15 Ibidem, 6.

16 Ibidem, 7.

${ }^{17}$ Nesse sentido, é provável que, conforme nos sugere Cunha (2012, p. 420), o termo "inteligir" fosse bem mais apropriado por força da correção terminológica; porém, o termo carece de uso mais extensivo na língua.

18 Sermo XLIII, 3.

19 Ibidem, 9.
} 
da razão em relação à fé não significa atribuir uma equivocada primazia da racionalidade sobre a fé. A máxima proferida pelo bispo de Hipona "intellege ut credas, crede ut intellegas" ${ }^{20}$, deve ser, portanto, interpretada à luz da exigência que a circularidade fé e razão impõe, a saber: o reconhecimento da existência de uma capacidade cognitiva no ser humano que o permita compreender o anúncio da fé cristã; pois, do contrário, não seria possível sequer crer no verbum Dei. A dialética ${ }^{21}$ aqui expressa consiste, então, em compreender o anúncio daquilo em que se deve crer; compreendendo, deve-se crer, e, crendo, deve-se procurar alcançar a inteligência daquilo em que se tem crido.

Essa circularidade encontra fundamentação e maior acuracidade em importante consideração realizada por Agostinho ainda no início da homilia, a saber: a distinção entre os termos intellectus e ratio, traduzidos nessa passagem, respectivamente, como "inteligência" e "razão":

Porque uma coisa é a inteligência, e outra, a razão. A razão, possuímo-la antes de compreender; pois, do contrário, não poderíamos compreender se não tivéssemos a razão. Portanto, o homem é um animal capaz de razão; para dizer de forma mais clara e rápida: um animal racional cuja natureza é parte da razão; antes de compreender, possui a razão. Se quer, pois, compreender é porque precede a razão ${ }^{22}$.

O termo intellectus, conforme expresso neste excerto, refere-se a uma faculdade da alma superior à razão. A superioridade do intellectus sobre a ratio se dá, na concepção agostiniana, pelo fato de que seria possível haver razão, sem contudo, possuir inteligência, mas o contrário não seria possível. Intellectus e intelligentia são termos correlatos,

\footnotetext{
${ }^{20}$ Ibidem, 9.

${ }^{21}$ A pluralidade de significações do termo "dialética" é evidenciada ao longo do próprio corpus agostiniano. Assim, qualquer definição deste termo, interpretada de maneira unívoca na obra agostiniana, apresenta-se como inverossímil (cf. FITZGERALD, Diccionario de San Agustín, p. 394-398). Apesar da complexidade de significações e das utilizações plurais deste termo na reflexão agostiniana e na própria tradição filosófica, "dialética" se emprega, neste artigo, em seu sentido puramente dialógico, ou seja, numa relação na qual se estabelece uma espécie de acordo e mutualidade (cf. MORA, Dicionário de filosofia, p. 718-727). Dessarte, a presente pesquisa pressupõe uma relação de mutualidade no centro do nexo entre fé e razão proposto por Agostinho, transcendendo, assim, a mera aproximação de termos completamente distintos e independentes.

22 Sermo XLIII, 2.
} 
os quais designam uma visão interior que, iluminada pela graça divina, percebe a Verdade ${ }^{23}$.

Nosso autor estabelece, então, uma importante distinção entre compreender, enquanto capacidade de assimilar o que se enuncia (ratio), e compreender, enquanto alcance da plenitude da inteligência da fé (intellectus). Nesse sentido, a ratio, como estrutura cognitiva, precede a fides e a fides precede o intellectus. Daí advém que: "compreendo para crer e creio para compreender"; e, de igual modo, "creio para compreender, e compreendo para crer".

A fé, na acepção agostiniana, não prescinde, pois, da razão; antes, o ato de crer impõe, por si mesmo, a tarefa do pensar. Na Epistula $C X X$, de cerca de $410^{24}$ d.C., Agostinho instruiu a um certo Consêncio sobre essa questão. Este procurava encontrar, na fé cristã, as condições suficientes para prescindir do exercício teorético, especialmente da sofisticação racional da filosofia. Nesse intuito, Consêncio escreveu a Agostinho $^{25}$ pedindo-lhe que o instruísse sobre a Santíssima Trindade, porém, de maneira livre das amarras da racionalidade especulativa, pois, conforme julgou aquele, a fé, diferentemente do refinamento do espírito especulativo, não se restringe a determinada elite intelectual. À vista disso, Agostinho escreveu-lhe, então, essa epístola, provendo a seguinte orientação quanto ao problema:

Com efeito, quando começares a introduzir-te de algum modo na inteligência deste grande mistério (coisa que eu não posso fazer se Deus não o ajudar interiormente), não irei fazer no meu ensaio outra coisa que dar-te minha razão, como puder. É razoável quando tu pedes para que eu ou qualquer outro doutor te ensine para que entendas o que crês? Deves tu, pois, corrigir tua convicção. Não que vás rechaçar a fé, senão que contemplarás também com a luz da razão o que, com a firmeza da fé, tu já admitias ${ }^{26}$.

${ }^{23}$ A significação do termo intellectus, à luz do contexto do Sermão 43, não difere, em absoluto, da definição deste vocábulo dada por Étienne Gilson. Portanto, segue-se aqui a explicação deste conceito, conforme propõe Gilson em Introdução ao estudo de Santo Agostinho. Vide GILSON, 2010, p. 96.

${ }^{24}$ Conforme data sugerida na edição da Biblioteca de Autores Cristianos.

${ }^{25}$ A carta de Consêncio consta no corpus agostiniano como Epistula CXIX. Todas as traduções de excertos do epistolário agostiniano neste trabalho são nossas, a partir das versões espanholas da Biblioteca de Autores Cristianos.

${ }^{26}$ Epistula CXIX, 2. 
Contrariando as expectativas de Consêncio, Santo Agostinho o exortou quanto à importância de se preparar para dar razões de sua fé e esperança cristãs, conforme ensinam as Escrituras ${ }^{27}$. Por esse motivo, o exercício racional consistiria numa capacidade legítima e singular do espírito humano, sem a qual não haveria possibilidade para a fé. Consêncio, então, não deveria abdicar do exercício racional nem sequer se esquivar dele, alegando que, devido à racionalidade filosófica, por exemplo, muitos se distanciaram da fé cristã. Agostinho o interpelou nesses termos: "Vamos dizer que precisamos evitar qualquer discurso porque existem discursos falsos? Igualmente não deves evitar toda razão porque existe alguma razão falsa"28. Declinar do desafio de refletir racionalmente a fé cristã seria, portanto, um enorme equívoco:

Deus está longe de odiar em nós essa faculdade pela qual nos criou superiores aos outros animais. Ele nos livre de pensar que a nossa fé nos incita a não aceitar ou buscar a razão, pois não poderíamos sequer crer se não tivéssemos almas racionais ${ }^{29}$.

As pretensões do interlocutor foram colocadas em xeque. Qualquer intenção de desenvolver um discurso crente, que, todavia, o impelisse a abdicar da racionalidade da fé, isto é, a prescindir da razão humana no alcance da inteligência do mysterium fidei, equivaleria a um desprezo à criação divina, porque, segundo Santo Doutor, não foi outra causa senão o próprio Deus que graciosamente criou os humanos como seres racionais, distinguindo-os, por essa razão, dos irracionais.

Os crentes são, por conseguinte, capazes de crer justamente porque são seres racionais, aptos a cogitar; do contrário, a possibilidade de crer lhes seria privada. Nesse sentido, a fides quae (ou seja, os conteúdos da fé cristã, a dimensão objetiva da fé) pressupõe a razão como condição essencial para a apreensão e comunicação dos conteúdos interpretados como revelação do próprio Deus. De igual modo, a fides qua (isto é, a própria dimensão subjetiva da crença) não surge de uma lacuna na existência humana. Agostinho se distancia do fideísmo irracionalista, pois não propõe qualquer espécie de nulidade racional

\footnotetext{
${ }^{27}$ Ibidem, 4.

${ }^{28}$ Ibidem, 6.

${ }^{29}$ Epistula CXIX, 3.
} 
inicial como exigência para que o próprio ato subjetivo de crer se afirme como tal ${ }^{30}$.

Assim, é inevitável o regresso à máxima presente no De praedestinatione sanctorum, a saber: "[...] o fato mesmo de crer nada mais é do que cogitar com assentimento" 31 . O retorno a essa definição é necessário, porque, após elucidar que a fé é, essencialmente, uma atividade do espírito humano, isto é, que a crença é um cogitar, impõe-se a necessidade de esclarecer a natureza desse cogitar, pois, na acepção de Santo Agostinho, a fides qua, neste caso, o horizonte da subjetividade da fé do cristão, não é um ato racional qualquer, na medida em que não coincide com uma atitude despretensiosa, falseada ou ilusória, senão com um cogitar efetivamente assentido.

Contudo, antes de analisar o problema do assentimento da fé, convém compreender, primeiramente, a crença num horizonte mais amplo. Nesse sentido, a obra De utilitate credendi ${ }^{32}$ traz algumas considerações indispensáveis ao tratamento da questão. A referida obra, escrita cerca de 391-392 d.C. ${ }^{33}$, foi destinada a Honorato, um amigo da seita maniqueia. $\mathrm{O}$ escrito possui uma preocupação simetricamente oposta à carta que anos depois seria enviada a Consêncio. Enquanto este questionou o valor da perspicácia racional na construção do discurso crente, Honorato, tempos antes, almejou justamente o inverso, ou seja, uma explicação claramente racional do conteúdo da verdade em que se deve crer.

A polêmica, aqui, tem como alvo o maniqueísmo. Os adeptos deste círculo religioso desprezavam e escarneciam a mensagem da fé católica. A exigência de se crer antes mesmo de se compreender a plenitude das verdades eternas era, na concepção maniqueísta, absurda e, por conseguinte, inadmissível. A relação entre fé e razão constitui, portanto, um aspecto capital desta obra. Com admirável agudeza de espírito, o bispo de Hipona retorquiu as críticas maniqueístas à inteligência da fé católica e se opôs diretamente a um sério problema, intimamente relacionado à própria questão da racionalidade da fé, a saber: a recusa ímpia e nociva à autoridade, bem como a legitimidade da revelação presente no Antigo Testamento.

\footnotetext{
${ }^{30}$ ROSA, J. A credibilidade da fé, p. 7-30.

${ }^{31}$ De praedestinatione sanctorum II, 5.

32 Tradução nossa, aqui e alhures, a partir da tradução espanhola, De la utilidad de crer, da Biblioteca de Autores Cristianos.

${ }^{33}$ LANCEL, S. Saint Augustin.
} 
Nesse cenário, Santo Agostinho desenvolveu uma reflexão sobre a importância da fé para a vida humana. A crença, segundo ele, não se restringe a uma adesão à revelação cristã nem a qualquer outra expressão cúltica. Ao contrário, o ato de crer se estende para domínios da existência humana não propriamente religiosos. Sem essa dimensão cotidiana da fé, a vida social humana estaria fadada à ruína completa: "Diversas razões poderiam ser citadas para demonstrar que não restaria nada na sociedade humana se nos determinássemos a não crer além do que podemos perceber por nós mesmos" 34 .

Conforme Agostinho, situações pessoais vivenciadas num passado, que, por alguma razão, são inacessíveis à memória; eventos históricos ocorridos em épocas remotas, mas que, todavia, são de conhecimento popular; e, bem assim, a origem paterna e materna de alguém são exemplos de questões que, em princípio, são reconhecidas e assimiladas como verdadeiras a partir da crença na autoridade de um determinado testemunho. Outro exemplo a se considerar consiste no fato de que, antes de conhecer determinada ciência, é necessário que, ainda que provisoriamente, primeiro se acolha a autoridade do mestre que, versado na área, ensina os seus quanto aos conteúdos fundamentais deste determinado saber.

As próprias relações humanas são fundadas em crenças, pois não se tem acesso direto à interioridade do outro. As intenções e os sentimentos de outrem são, em certo sentido, furtivos ${ }^{35}$. Nesse sentido, no De fide rerum quae non videntur ${ }^{36}$, Santo Agostinho, por volta de oito a nove anos após ter escrito o De utilitate credendi ${ }^{37}$, retomou aquele argumento com que interpelou seu leitores: "Como vês o afeto de teu amigo? Porque o afeto não podes ver com os olhos corporais" 38 .

No De fide rerum quae non videntur, o problema da credibilidade da fé ocupa novamente o centro do temário presente na reflexão agostiniana. Semelhantemente ao que ocorre no De utilitate credendi, aí nosso filósofo procura demonstrar que a fé é uma virtude necessária para a vida humana. Caso desaparecesse a fé, a vida social seria impossível:

\footnotetext{
${ }^{34}$ De utilitate credendi, XII, 26.

${ }^{35}$ Cf. De utilitate credendi, X, 23.

36 Tradução nossa, aqui e alhures, a partir da tradução, De la fé en lo que no se ve, da coleção Obras de San Agustín.

${ }^{37}$ RODRÍGUEZ, H. Introducción, p. 791-792.

${ }^{38}$ De fide rerum quae non videntur, I, 2.
} 
Quem não percebe quão grande perturbação, que confusão espantosa sobreviria se a fé desaparecesse da sociedade humana? Sendo o amor invisível, como se amarão mutualmente os seres humanos se não creem no que não podem ver? Desaparecerá a amizade, pois se funda no amor recíproco. Que testemunho de amor receberá um ser humano de outro se não crer que o pode dar? Destruída a amizade, não se poderá conservar na alma os laços do matrimônio, do parentesco e da afinidade, porque neles existe, também, a relação amistosa. E assim, nenhum marido amará a esposa, nem ela ao marido, se não crer no amor recíproco que não podem ver. Nem desejarão ter filhos, porque não creem que possam concebê-los [...]. Se não cremos no que não vemos, se não admitimos a boa vontade dos outros, porque não podemos alcançá-la com nossos olhos, perturbar-se-ão as relações entre os homens de tal maneira que a vida social seria impossível ${ }^{39}$.

Em Confessionum ${ }^{40}$, Santo Agostinho também menciona a dimensão cotidiana do ato de crer. Nesse clássico, aludindo criticamente ao problema do racionalismo maniqueísta, declarou:

Depois, Senhor, tu, pouco a pouco tocando e ordenando o meu coração com mão suavíssima e misericordiosíssima, considerando eu quão numerosas eram as coisas em que acreditava sem que eu as visse ou estivesse presente ao serem feitas, como tantas coisas na história dos povos, tanto sobre lugares e cidades que nunca vira, tantas em relação a amigos, tantas quanto a médicos, tantas sobre estas ou aquelas pessoas, tantas coisas em que, se não acreditássemos, absolutamente nada faríamos nesta vida, e finalmente, considerando eu quão inabalavelmente conservava fixo na minha convicção de que pais tinha nascido, coisa que eu não podia saber se não tivesse acreditado no que ouvia $[\ldots]^{41}$.

No De diversibus quaestionibus, Santo Agostinho, na questão intitulada De credibilibus distinguiu três gêneros de crenças: no primeiro caso, encontram-se os exemplos supramencionados. Estes serão sempre objeto de crença; no entanto, nunca serão compreendidos plenamente; o segundo gênero corresponde aos que se compreendem logo que se

\footnotetext{
${ }^{39}$ Ibidem, II, 4.

${ }^{40}$ As citações desse texto advêm da tradução portuguesa de Arnaldo do Espírito Santo, João Beato e Maria Cristina de Castro-Maia de Souza Pimentel.

${ }^{41}$ Confessionum, VI, 5, 7.
} 
crê. A estes ele se refere como rationes humanae. Os conhecimentos matemáticos e as diversas ciências são exemplos destas razões humanas; o terceiro e último gênero de crença se refere à fé cristã e a sua exigência de se crer como condição para poder alcançar a plenitude do conhecimento ${ }^{42}$.

Contudo, o grande problema em jogo não é simplesmente a crença em sua dimensão cotidiana, ou a das verdades matemáticas. Santo Agostinho reorienta a questão da fé ordinária para o plano da transcendência. Nesse sentido, a crença que se almeja legitimar é aquela fundada na revelação cristã; é aquela fé que questiona toda forma de soberba e ingenuidade oriunda do estabelecimento da razão em sua plena autonomia e pretensão de apreender a totalidade da realidade e do sentido último da existência humana. Em outros temos, a fé que se pensa é, sobretudo, a fé teologal.

Agostinho assegura, desse modo, que a exigência prévia do acolhimento de uma determinada autoridade se dá, na ordem da religiosidade, por razões ainda mais certas:

Porque crer sem razões quando ainda não estamos em condição de aprendê-las, e preparar o espírito por meio da fé mesma para receber a semente da verdade, eu tenho não só por saudável, senão por necessário para que as almas enfermas possam recobrar a saúde ${ }^{43}$.

Ora, o problema do De utilitate credendi e do De fide rerum quae non videntur se dá justamente nesses termos. $\mathrm{O}$ argumento da fé como dimensão essencial para a vida cotidiana se dá tendo em vista a validação da exigência imposta pela religião cristã de se crer antes de se chegar ao conhecimento perfeito do intellectus fidei. Conforme elucidado, Agostinho de Hipona considerou a anterioridade do ato de crer como condição imprescindível para que as almas enfermas pudessem, posteriormente, alcançar a saúde perfeita, ou seja, o conhecimento da Verdade Beatífica.

O aforismo nisi credideritis, non intelligetis consiste, portanto, num aspecto capital da filosofia cristã ${ }^{44}$. Com efeito, ao analisar a perícope do Evangelho de João, 7,14-18, Santo Agostinho, no notável comentário

\footnotetext{
${ }^{42}$ Cf. Diversibus quaestionibus, XLVIII.

${ }^{43}$ De utilitate credendi, XIV, 31.

${ }^{44}$ GILSON, E. L'avenir de la métaphysique augustinienne.
} 
In evangelium Ioannis tractatus ${ }^{45}$, expressou a exigência da anterioridade da fé nos seguintes termos: "[...] crês porque não compreendes, e crendo, torna-te capaz de compreender. Se não creres, nunca compreenderás, porque permanecerás menos apto. A fé, pois, te purifique para que vejas a plenitude da inteligência" 46 .

Ainda neste mesmo tratado, Santo Agostinho insistiu:

$\mathrm{O}$ que se prometeu aos que creem, irmãos? 'E conhecereis a verdade'. [...] pois cremos para conhecer, não conhecemos para crer. O que conheceremos nem 'olhos viram, nem ouvidos ouviram, nem o coração do homem imaginou'. O que é, pois, a fé, senão crer no que não se vê? ${ }^{47}$

A inegociável exigência da anterioridade da fé reivindica, segundo Santo Agostinho, uma autoridade que transcenda o simples ato subjetivo de crer. A crença, pressupõe, portanto, um assentimento justificado, fiado em certas garantias. A articulação, pois, entre cogitatio e assentio é governada pela noção de auctoritas $^{48}$. Nesse sentido, o De fide rerum quae non videntur assegurou, por exemplo, a legitimidade da fé cristã a partir da autoridade singular do testemunho profético:

Muito se equivocam os que pensam que sem provas suficientes cremos em Cristo. Qual prova é mais evidente do que o cumprimento das profecias? Portanto, os que pensam que não existe nenhum motivo para crer em Cristo, que não o viram, considerem então o que estão vendo ${ }^{49}$.

Neste excerto, apela-se à autoridade da mensagem profética como evidência da validade da fé evangélica. Contudo, apesar de direcionar o olhar dos não crentes, exortando-os para que atentem para o cumprimento

45 Tradução nossa, aqui e alhures, a partir da tradução ao espanhol intitulada Tratados sobre el Evangelio de San Juan.

${ }^{46}$ In evangelium Ioannis tractatus, XXXVI, 7.

${ }^{47}$ Ibidem, XL, 9.

${ }^{48} \mathrm{KOCH}$, I. Sobre a definição agostiniana de crença, p. 15-24. A esse respeito, Brachtendorf (Confissões de Agostinho, p. 129) esclarece: “A crença na autoridade, portanto, deve vir antes, mas ela representa apenas uma procura. Quem prosseguir nesse caminho chegará à intelecção e aprenderá cognitivamente o que procurou sob a orientação da autoridade". Com efeito, a fé fundada na autoridade não prescinde do exercício cognitivo. Sua função consiste em orientar a razão quanto ao caminho que esta deverá seguir. A noção de auctoritas, portanto, não se desdobra em qualquer concepção do tipo fideísta.

${ }^{49}$ De fide rerum quae non videntur, III, 5. 
das profecias e, a partir daí, creiam, Agostinho não desejou, com isso, assentar a percepção sensível como critério para o saber, ou ainda, como fundamento último da fé. Ora, na concepção agostiniana, a referência à autoridade não se dá apenas em termos de uma garantia fundada numa prescrição exterior, captada pelos sentidos.

Com efeito, no livro XIII do De Trinitate, o bispo de Hipona indicou a fonte da inspiração da fé cristã. Segundo ele: "Esta fé, porém, promete, não pela argumentação humana, mas pela autoridade divina, que o homem todo, que é constituído de alma e corpo, será imortal, e, por isso, verdadeiramente feliz" ${ }^{50}$. Nesta passagem, assinala incisivamente que a esperança do discurso crente se fixa, sem margem para a dúvida, na divina auctoritas.

$\mathrm{Na}$ filosofia agostiniana, a divina auctoritas, conforme se mencionou, não diz respeito, entretanto, à referência a uma autoridade estritamente externa ao ser humano. Apesar dessa autoridade transcendêlo, é no mais íntimo de seu ser que ela se manifesta como presença atuante ${ }^{51}$. Agostinho, portanto, recorre a uma justificação da fé a partir de uma atestação íntima, ou seja, por um viés internalista que recorre à Praesentia interiora como divina auctoritas.

A Praesentia interiora, que assegura das promessas da fé, direciona os puros de coração, da procura pela Verdade nos ruídos exteriores para a alegria da contemplação no sossego interior ${ }^{52}$ : "Porque havemos de sair correndo a procurar, no mais alto do céu ou nas profundezas da terra, aquele que está em nós se nós quisermos estar nele?"53. Esta Praesentia interiora, que verdadeiramente vem a ser a fonte da inspiração da atitude crente, é o próprio Deus que, por sua graça, deixa-se encontrar no mais íntimo da alma humana e, deste interior clama, a fim de romper a surdez dos que se precipitam em encontrar a Verdade apenas por meio dos sentidos externos:

${ }_{50}$ De Trinitate, XIII, 9, 12. De acordo com a tradução utilizada neste artigo, a saber: SANTO AGOSTINHO. Trindade - De Trinitate: edição bilíngue. Tradução: Arnaldo do Espírito Sando, Domingos Lucas Dias, João Beato, Maria Cristina de Castro-Maia de Souza Pimentel. Prior Velho, 2007.

${ }^{51}$ LIMA VAZ, H. A metafísica da interioridade, p. 93-106.

52 "San Agustín representa una filosofia que parte del hombre y vuelve al hombre, pero cargada ya de la presencia que el refleja de lo divino. Por eso comienza con la vuelta del espírito a sí mismo, busca la verdad, no la verdad existencial de cada uno, sino la verdad eterna, que nos lleva en su resplandor a contemplar la presencia de Dios en el hombre. No se queda esta contemplación en el hombre, sino que se trasciende y se eleva a la Verdad misma" (CABA, La filosofía del conocimiento en san Agustín, p. 216-217).

${ }^{53}$ De Trinitate, VIII, 7, 11. 
Tarde te amei, beleza tão antiga e tão nova, tarde te amei! E eis que estavas dentro de mim e eu fora, e aí te procurava, e eu, sem beleza, precipitava-me nessas coisas belas que tu fizeste. Tu estavas comigo e eu não estava contigo. Retinham-me longe de ti aquelas coisas que não seriam, se em ti não fossem. Chamaste, e clamaste, e rompeste a minha surdez, brilhaste, cintilaste, e afastaste a minha cegueira; exalaste o teu perfume, e eu aspirei e suspiro por ti, e tenho fome e sede, tocaste-me, e abrasei-me no desejo da tua paz $^{54}$.

O caminho da interioridade, entretanto, não reduz o valor e a autoridade da mensagem das Escrituras. Ao contrário, segundo a reflexão agostiniana, a fé capaz de transformar a existência humana é justamente a fé salvífica que surge do encontro do homem com a revelação cristã. Ao termo do De Trinitate, Santo Agostinho exorta a seus leitores dizendo:

E, quando tiverem acreditado inabalavelmente nas Sagradas Escrituras como as mais verdadeiras testemunhas, façam, rezando, e procurando, e vivendo segundo o bem, por entender, isto é, façam que aquilo que é possuído pela fé seja visto pela mente tanto quanto é possível ${ }^{55}$.

Desse modo, a verdadeira crença encontra alicerce na Verdade revelada nas Escrituras Sagradas e manifesta concretamente no interior do ser humano. Nesse cenário, o caminho da interioridade e a revelação bíblica compõem harmoniosamente a estrutura fundamental da argumentação agostiniana no De Trinitate. Na verdade, apenas um olhar mediado pelos dados da revelação bíblica, quando dirigido para si mesmo, para a parte mais sublime e interior da alma, pode alcançar a Verdade, isto é, vislumbrar, até o possível, certa visão das promessas aludidas pela fé.

À luz do exposto até aqui, situa-se então o sentido da exigência epistêmica da filosofia cristã: Nisi credideritis non intelelligetis - "Se não é possível alcançá-lo por meio da inteligência, agarremo-lo por meio da fé, até que brilhe nos corações aquele que diz pelo Profeta: Se não acreditardes, não compreendereis" ${ }^{\prime 56}$. Esse postulado, longe de

\footnotetext{
${ }^{54}$ Confessionum, $\mathrm{X}, 27,38$.

${ }^{55}$ De Trinitate, XV, 27, 49.

${ }^{56}$ De Trinitate, VII, 6, 12.
} 
quaisquer obscurantismos, convida o ser humano ao aprofundamento no mysterium fidei, a fim de alcançar, por meio da inteligência, aquilo para que a fé insiste em apontar. Nesse cenário, se dá, portanto, a realização da síntese do método agostiniano, a saber: a sentença credo ut intelligam, intelligo ut credam, ou seja, "creio para compreender, compreendo para crer".

Conforme Agostinho, a fé descreve uma esperança, indica um horizonte de intelecção a ser aspirado pela razão. Os conteúdos indicados pela fé são primordiais para o alcance da compreensão do real significado da existência humana e da vida feliz. Certamente, a fé nas Escrituras proporciona alguns axiomas a partir dos quais a Verdade precisa ser investigada. À luz, a razão deve perseguir as pistas da fé em uma investigação em direção à Verdade Eterna anunciada pela fé, isto é, ao próprio Deus-Trindade. Desse modo, fé e razão não são apenas coincidentes e compatíveis, mas, em seu elo dialético, versam sobre os mesmos domínios e compartilham os mesmos conteúdos, ainda que por meios diferentes ${ }^{57}$.

$\mathrm{Na}$ verdade, a experiência crente consiste na expressão do amadurecimento da própria razão. Diante da vivência da fé, a razão humana, temporal e condicionada pelas vicissitudes da existência mundana, ao indagar sobre sua real natureza, percebe que deverá fazêlo paradoxalmente, reconhecendo a necessidade de ir para muito além de si mesma, a um outro que, no entanto, não é irracional. A razão, portanto, deverá transcender-se em direção à fonte de sua verdadeira identidade. $\mathrm{Na}$ concepção agostiniana, a razão não basta a si mesma; para fazer o percurso mencionado, carece do impulso da fé, das pistas assinaladas pela revelação cristã. Nesse sentido, a fé não é compreendida como uma atitude alheia à razão, mas justamente como o caminho que leva a razão ao reconhecimento de sua real identidade como extraposta, ou seja, não se reduzindo às amarras da temporalidade e da transitoriedade que, no momento presente, determinam-na ${ }^{58}$.

A fé no Deus eterno que adentrou a história se dá, assim, como exigência inegociável para a transição do conhecimento da ciência, ou seja, das coisas temporais e sensíveis para a verdadeira sabedoria, compreendida como contemplação das realidades eternas e imutáveis. Além do mais, é por meio da fé que os homens podem superar a

\footnotetext{
${ }^{57}$ NOVAES FILHO, M. A razão em exercício.

${ }^{58}$ Cf. Idem, p. 98.
} 
curiosidade pueril, pois não há outra, se não a própria fé, capaz de indicar, a priori, uma ordem de realidade superior, despertando a inteligência humana para a compreensão da necessidade de uma via ascensional, que, partindo da realidade intramundana, contemple a realidade transcendente.

Portanto, a fé se impõe a tarefa de salientar a incapacidade e incompletude da razão, para que, enfim, purificada de toda mácula, a razão possa ir além das imagens de temporalidade e materialidade que carrega consigo. No seio da relação entre fé e razão existe, então, uma importante oposição descrita na forma visibiliainvisibilia ou temporalialaeterna. Nesse sentido, a fé significa o percurso que conduz a razão humana da esfera do visível para o invisível, do temporal para as realidades eternas.

Por conseguinte, não apenas a razão, mas a própria fé não basta a si mesma, pois ela se encontra, também, na esfera da temporalidade. Mesmo condicionada a essa esfera, a fé, no entanto, vem a ser indispensável à razão, pois não há outra capaz de desvelar a significação da realidade visível. Dessa maneira, uma relação ordenada com a criação, ou seja, um envolvimento adequado com os elementos visíveis e temporais é possível se, e somente se, partir da inteligência da fé.

A fé, ainda que temporal, pode conduzir o ser humano para algo além dela mesma, para uma realidade que transcende sua própria contingência e limitação. Nesse sentido, a fé se dá em vista do eterno. O tempo da fé consiste, portanto, num tempo necessário para que o ser humano possa contemplar, na era vindoura, a Verdade: "Dessa forma, não desprezemos o tempo da fé, como o tempo da semente, não desprezemos, mas perseveremos, até que colhamos o que tivermos semeado" 59 .

Por essa razão, não se trata meramente de crer e compreender, como se isso fosse um fim em si mesmo, senão para alcançar um determinado objetivo. A relação dialética crer e compreender é, conforme já se expôs, uma procura pelo conhecimento de Deus. Deve-se crer a fim de buscar compreender e, compreendendo melhor, deve-se buscar com intensidade ainda maior. O paradoxo aqui subjacente não implica a existência de uma relação viciosa, como se o espírito circulasse sobre si mesmo num imenso vazio; a dialética fé e razão encontra sentido e significado apenas na Verdade que a transcende. A relação fé e razão vislumbra o

\footnotetext{
${ }^{59}$ Sermo XLIII, 1.
} 
alcance de algo muito além de uma simples circularidade ensimesmada. Essa relação aponta para fora de si, para o gozo da contemplação do mysterium Trinitatis na vida eterna.

A busca pela felicidade inextinguível se inicia com a fé e se realiza no conhecimento de Deus. A fé, indiscutivelmente essencial para o alcance da vida feliz, solicita um aprofundamento reflexivo dos conteúdos apontados por ela mesma. No entanto, esta questão não se restringe à esfera da pura investigação racional das verdades da fé. Conforme Santo Agostinho, o ato de crer em Deus é mais do que uma simples concordância intelectual com a revelação cristã. A fé, em sua capacidade de conduzir o ser humano a vivenciar a realização eterna da vida feliz, implica da parte deste uma entrega irres$\operatorname{trita}^{60}$ :

O que é, pois, a fé n'Ele? É uma fé amante, uma fé plena de amor, uma fé que te conduz a Ele e te incorpora em seus membros. Esta é a fé que Deus nos exige. [...] Não se trata de uma fé qualquer, mas da fé que age mediante o amor. Haja em ti essa fé e compreenderás a doutrina ${ }^{61}$.

No nível das relações entre fé e razão, o De Trinitate apresenta um terceiro termo, indispensável à progressão do conhecimento de Deus, a saber: o amor. Nesse sentido, os atentos leitores são instruídos: "A menos que o amemos agora, jamais o veremos"62. Ainda, noutra importante obra, ele desenvolve a seguinte fórmula: "Não se chega à verdade senão pelo amor"63. Destarte, crer em Deus, conforme Santo Agostinho, significa penetrar no seu mistério de amor.

\footnotetext{
60 "Y, ¿por qué es necesario creer, antes de entender? Porque la fe opera una transformación, una $\mu \varepsilon \tau$ óvi $\alpha$ [sic] en el hombre". [...] la concepción más plenaria de los Santos Padres y, entre ellos, especialmente de san Agustín, que concibe el acto de fe, además y sobre todo, como credere in Deo, como una entrega confiada de toda la persona a un Dios que es amor y que se revela al hombre para invitarle a entrar en su amistad. La fe así concebida es ante todo una conversión. Por tanto, no solamente ilumina la razón, sino que sobre todo crea en el hombre una actitud de buena voluntad, de amor sincero de la verdad" (PEGUEROLES, El pensamiento filosófico de San Agustín, p. 18).

${ }^{61}$ In evangelium Ioannis, XXIX, 6.

${ }^{62}$ De Trinitate, VIII, 4, 6.

${ }^{63}$ Contra Faustum, XXXII, 18. Tradução nossa, a partir da versão em espanhol, Contra Fausto, da coleção Biblioteca de Autores Cristianos.
} 


\section{Considerações Finais}

O problema fundamental aqui analisado, qual seja, o da própria inteligência da fé foi pensado a partir de uma relação dialógica entre fé e razão expressa na máxima credo ut intelligam, intelligo ut credam. Conforme Santo Agostinho, através dessa relação, o espírito encontra as condições necessárias para se debruçar sobre a investigação do conhecimento de Deus.

A proposta deste artigo, no entanto, mantém distância da pretensão de sustentar uma leitura dogmatizante, ou canônica, de Agostinho. Nesse sentido, ainda que a ênfase da interpretação aqui realizada não tenha recaído sobre a especificidade das controvérsias entre os intérpretes contemporâneos, não se deve esquecer que a filosofia agostiniana foi sempre alvo de acalorados debates. Contudo, por razões metodológicas, nossa ênfase aqui recai sobre o necessário e profícuo diálogo interno entre as obras agostinianas, não sobre a problematização das diferentes interpretações do sentido da relação fé e razão em Agostinho.

Apesar do significativo mérito da conciliação entre fé e razão proposta por Agostinho, e de seu insigne legado para a tradição filosófica, tal síntese não finda com o drama da relação fé e razão. Seria um contrassenso lastimável restringir esse problema à reflexão aqui apresentada, desconsiderando, outrossim, a especificidade do dilema à luz dos desafios suscitados pela inteligência moderna e contemporânea. Com efeito, realizar um resgate da filosofia agostiniana como um cânone sagrado na resolução desse dilema seria uma atitude demasiadamente desastrosa.

A relação fé e razão se propõe como um intrigante drama da existência humana. A complexidade desse dilema ganhou a devida atenção na reflexão agostiniana e tem concitado a inteligência cristã a desenvolver proficientes ensaios. Santo Agostinho, em seu filosofar na fé, indicou a possibilidade da reflexão sobre a relação fé e razão, sem, entanto, culminar numa rejeição arbitrária da fé ou em algum estreitamento idealístico do tipo fideísta, ainda que mitigado. Contudo, para além de uma simples querela patrística ou medieval, o esforço de elucidação da razoabilidade da fé projeta-se ainda como um caro dilema para a inteligência contemporânea. 


\section{Referências}

BÍBLIA. Português. Bíblia Sagrada. Almeida Século 21. São Paulo: Vida Nova; Hagnos, 2008.

BÍBLIA. Português. Bíblia de Jerusalém. Nova edição, revista e ampliada. São Paulo: Paulus, 2002.

BRACHTENDORF. Johannes. Confissões de Agostinho. Tradução de Milton Camargo Mota. São Paulo: Edições Loyola, 2008.

CABA, Pedro. La filosofía del conocimiento en san Agustín. Augustinus, La Rioja, v. 3, p. 215-226, 1958.

CUNHA, Mariana Paolozzi Sévulo da. Santo Agostinho: fé e razão na busca da verdade. Perspectiva Teológica, Belo Horizonte, ano 44, n. 124, p. 415-427, set./dez. 2012.

DU ROY, Oliver. L'intelligence de la foi en la Trinité selon Saint Augustin: genèse de sa théologie trinitaire jusqu'en 391. Paris: Institut d'Éstudes Augustiniennes, 1966.

FITZGERALD, Allan D. Diccionario de San Agustin: San Agustín a través del tiempo. Burgo: Editorial Monte Carmelo, 2001.

GILSON, Étienne. Introdução ao estudo de Santo Agostinho. Tradução de Cristiane Negreiros Abbud Ayoub. 2.ed. São Paulo: Discurso Editorial; Paulus, 2010.

1931.

. L'avenir de la métaphysique augustinienne: Mélanges Augustiniens: Paris,

JOÃO PAULO II. Fides et ratio. Disponível em: < http://w2.vatican.va/content/ john-paul-ii/pt/encyclicals/documents/hf_jp-ii_enc_14091998 fides-et-ratio.html $>$. Acessado em: 8 mar, 2014.

KOCH, Isabelle. Sobre a definição agostiniana de crença. Tradução de Luiz Marcos da Silva Filho e Moacyr Novaes. Síntese, Belo Horizonte, v. 42, n. 132, p. 15-24, 2015.

LANCEL, Serge. Saint Augustin. Paris: Arthème Fayard, 1999.

LIMA VAZ, Henrique Cláudio. A metafísica da interioridade: Santo Agostinho. In: LIMA VAZ, Henrique Cláudio. (Org.). Ontologia e história. São Paulo: Livraria Duas Cidades, 1968. p. 93-106.

MARROU, Henri-Iréné. Saint Augustin et la fin de la culture antique. Paris: E. DeBoccard, 1938.

MATTHEWS, Gareth B. Fé e razão. In: Santo Agostinho: a vida e as ideias de um filósofo adiante de seu tempo. Tradução de Álvaro Cabral. Rio de Janeiro: Jorge Zahar Editor, 2007. p. 135-148.

MORA, José Ferrater. Dicionário de filosofia. Tradução de Maria Stela Gonçalves et al. São Paulo: Loyola, 2001.

NOVAES FILHO, Moacyr Ayres. A razão em exercício: estudos sobre a filosofia de Agostinho. 2. ed. São Paulo: Discurso Editorial; São Paulo: Paulus, 2009.

PEGUEROLES, Juan. El pensamiento filosófico de San Agustín. Barcelona: Labor, 1972. 
ROSA, José Maria Silva. A credibilidade da fé: fenomenologia da existência crente. In: A Transmissão do património cultural e religioso. Lisboa, Edições Paulinas, 2005. p. 7-30.

RODRÍGUEZ, P. Hermínio. Introducción. In: Obras de San Agustín: obras apologéticas. Madrid: Biblioteca de Autores Cristianos, 1948. Tomo IV, p. 791-792.

ROY, Olivier du. L'intelligence de la foi en la Trinité selon Saint Augustin: genèse de sa théologie trinitaire jusq'en 391. Paris: Etudes Augustiniennes, 1966.

SAN AGUSTÍN. Carta CXIX. In: Obras de San Agustín: Cartas. Edición bilingue. Traducción de Loppe Cilleruelo. 3. ed. Madri: Biblioteca de Autores Cristianos, 1986. Tomo VIII, p. 882-888.

. Contra Fausto. In: Obras de San Agustín: Escritos antimaniqueos (2). Edición bilingue. Traducción de Pio Luis. Madrid: Biblioteca de Autores Cristianos, 1993. Tomo XXXI.

. De la utilidad de creer. In: Obras de San Agustín: obras apologéticas. Edición bilingue. Madrid: Biblioteca de Autores Cristianos, 1948. Tomo IV, p. 829-899.

. De la fé en lo que no se ve. In: Obras de San Agustín: obras apologéticas. Edición bilingue. Traducción de P. Herminio Rodríguez. Madrid: Biblioteca de Autores Cristianos, 1948. Tomo IV, p. 795-817.

. Sermón XLIII. In: Obras de San Agustín: Sermones (1) 1-50. Edición bilingue. Traducción de Miguel Fuertes Lanero y Moises $\mathrm{M}^{\mathrm{o}}$ Campos Madri: Biblioteca de Autores Cristianos, 1981. Tomo VII, p. 588-596.

. Tratados sobre el Evangelio de San Juan. In: Obras de San Agustín. Edición bilingue. Traducción de Teofilo Prieto. Madri: Biblioteca de Autores Cristianos, 1955. Tomo XIII.

. Tratados sobre el Evangelio de San Juan. In: Obras de San Agustín. Madri: Biblioteca de Autores Cristianos, 1965. Tomo XIV.

SANTO AGOSTINHO. Confissões: edição bilíngue. Tradução de Arnaldo do Espírito Sando, João Beato, Maria Cristina de Castro-Maia de Souza Pimentel. Lisboa: Imprensa Nacional - Casa da Moeda, 2001.

A predestinação dos santos. In: Graça (III). Tradução de Frei Agustino Belmonte. São Paulo: Paulus, 2008. (Coleção Patrística).

. Trindade - De Trinitate: edição bilíngue. Tradução de Arnaldo do Espírito

Santo, Domingos Lucas Dias, João Beato, Maria Cristina de Castro-Maia de Souza Pimentel. Prior Velho: Paulinas, 2007.

STEAD, Chistopher. A filosofia na antiguidade cristã. Tradução de Odilon Soares Leme. São Paulo: Paulus, 1999.

Recebido em: 13/10/2015

Aprovado em: 16/11/2015 